\title{
The Seawater Intrusion Indication Base on Resistivity Study on Merauke Regency, Papua Province, Indonesia
}

\author{
Virman $^{1 *}$, Endang Hartiningsih ${ }^{2}$, Rahmat Indrajati ${ }^{3}$, Karl K.W. Meak ${ }^{4}$ \\ ${ }^{1}$ Physic Education Study Program, Cenderawasih University \\ ${ }^{2}$ Geological Resource of Research Centre, Cenderawasih University \\ ${ }^{3}$ Mineral Technology Study Program, Cenderawasih University \\ ${ }^{4}$ Mining Engineering Study Program, Cenderawasih University \\ *Corresponding author. Email: virman_uncen@yahoo.com
}

\begin{abstract}
Seawater intrusion has a serious impact on the availability of fresh water for the population. Indication of seawater intrusion in several locations in Merauke Regency, Papua, showed by fluctuations of water quality in resident wells from fresh water into brackish water to salt water. The purpose of this study was to identify the occurrences of salted/brackish water, both in superficial and deep aquifers in Merauke Regency, Papua, using the geoelectric method of resistivity with Schlumberger configuration. There were four locations of measurements namely Merauke, Jagebob, Kurik and Semangga. Data processing was done using IPI2WIN software. Indication of seawater intrusion determined by resistivity value is $1.07-\mathrm{ohm} \mathrm{m}$ at $19.11 \mathrm{~m}$ depth in Merauke: $0.794-\mathrm{ohm} \mathrm{m}$ at $23.26 \mathrm{~m}$ depth in Semangga, and 0.329 -ohm $\mathrm{m}$ at $14.8 \mathrm{~m}$ depth in Kurik. There is no indication of seawater intrusion in Jagebob.
\end{abstract}

Keywords: Schlumberger, Merauke, Seawater, Groundwater.

\section{BACKGROUND}

Water is essential component in human civilization. The water molecule can occur as liquid, solid and gas phases. Water is very powerful solvent that responsible for the transfer of material on and below the earth's surface [1], [2]. Based on chloride content, water divided into fresh water and brackish water. Fresh water containing little $(<0,03 \%)$ or no chloride ion. On the other hand, brackish waters are saline water, but less so than sea water [3].

Intensive water exploitation in modern activities cause negative effects such as drying of wetlands, cease of base flow, induced land subsidence, ground cracks, degradation of riparian ecosystem and water quality, and aquifer depletion [4]. An aquifer predominantly consists of a body of permeable rocks which can store the significant quantities of water, and underlain by impermeable materials, and through that groundwater moves [1]-[3]. The freshwater from aquifer mainly used by population for household consumption, irrigation, and industry [5]. The freshwater consumption increasing as population increase year by year. Without good management in water consumption, it will affect the negative impact such as the lack of freshwater resource and decreasing the qualities of freshwater caused by seawater intrusion. Thus, the utilization of groundwater in an area has a certain limit to be used.

The seawater intrusion has a very wide impact on various aspects, such as human health problem, the decrease of soil fertility, the damage of buildings, and the lack of freshwater supplies [6]. The interaction between a dense wedge of saline groundwater fueled from the sea, and fresh terrestrial groundwater pouring in the direction of the sea can possibly cause seawater intrusion [7], [8]. Saltwater intrusion in coastal areas occurred where the water table is adjacent to the ground surface, and freshwater of the $\mathrm{CaHCO}_{3}$ type and seawater of the $\mathrm{NaCl}$ type mixes [9]. In this area, many residents unable to access the freshwater for daily consumption, because of the freshwater source has become a brackish water to saline water.

The Merauke City consists of two main area are coastal area and plain area, with elevation average is about 3 to $4 \mathrm{~m}$ [10]-[12]. This condition makes this city has a high risk in degradation of groundwater quality caused by seawater intrusion. The main purpose of this study is determining the seawater intrusion base on resistivity surveying in Merauke City. Electrical 
resistivity surveying methods have been extensively used to determine the resistivity and thickness of layered media for the groundwater potential exploration [13][18]. The groundwater resistivity value differs from 10 to $100 \Omega \mathrm{m}$ depending on the dissolved salts concentration, and the low resistivity (about $0.2 \Omega \mathrm{m}$ ) of seawater occurred because of the relatively high salt content [14]. This makes the resistivity method is suitable for mapping the freshwater and saline water interface in coastal areas, and also appropriate to determine the seawater intrusion into the freshwater aquifer phenomenon [6]-[8], [14], [19], [20].

Resistivity surveys are also used to investigate interfaces, such as surface of water tables or bedrock, which are approximately horizontal [17], [21], [22]. Current can be sent gradually deeper into the ground by moving electrodes further at a distance. Resistivities values can thus be predictable for progressively deeper levels, even though, unavoidably, resolution reductions as electrode separations increase [18], [21].
The basic principle of resistivity surveying is an electric current injection below the surface through the two electrodes $(\mathrm{AB} / 2)$, and the electric current will spread below the surface in all direction and perpendicular with the potential difference which is measured by two potential electrodes (MN/2) [14], [18], [21], [23]-[25]. The two important requirements of any resistivity survey are the introduction of current and the measurement of voltage, two current and two voltage electrodes are used in arrays that are usually, but not inevitably, linear. Current is generally provided over the outer electrodes and apparent resistivities determined using equation 1 as follows:

$\rho_{a}=K \frac{\Delta V}{I}$

with $\rho \_\mathrm{a}=$ apparent resistivity $(\mathrm{ohm} \mathrm{m}), \mathrm{K}=$ geometric faktor $(\mathrm{m}), \Delta \mathrm{V}=$ voltage (volt) and $\mathrm{I}=$ current $(\mathrm{mA})$. The geometric factor $(\mathrm{K})$ in resistivity method depends on the type of array or configuration used (Figure 1).

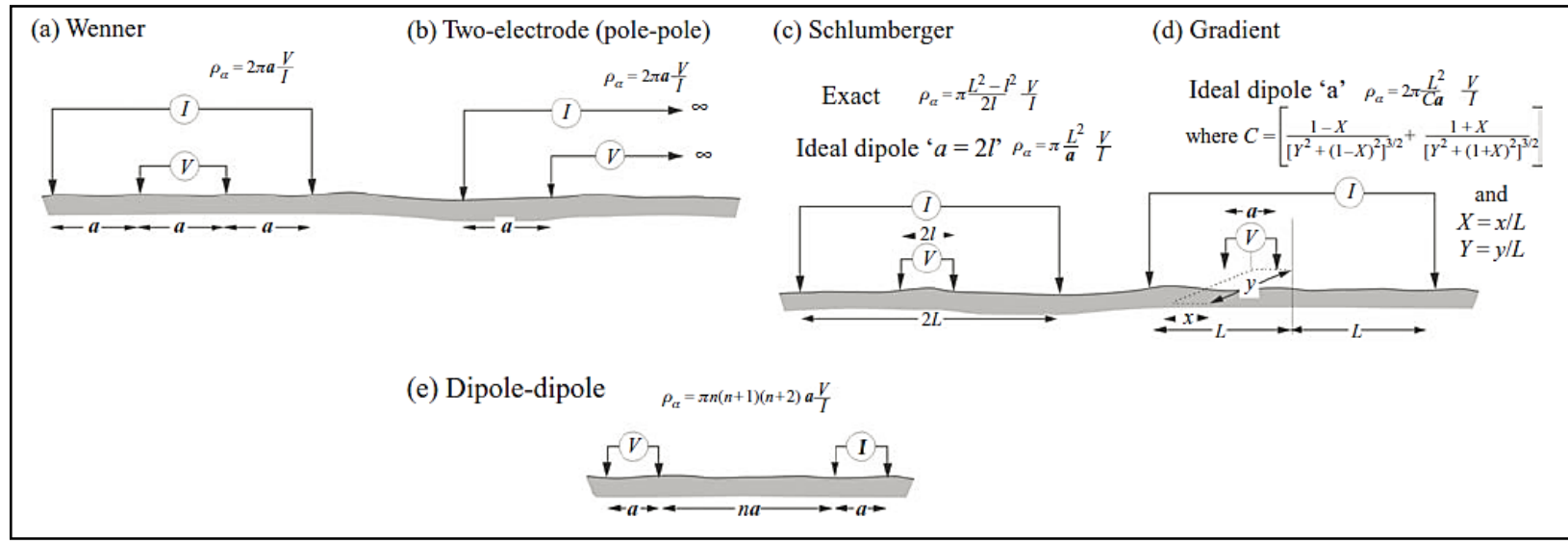

Figure 1 Arrays (configuration) and geometric conversion factors for resistivity and IP surveys: (a) Wenner array; (b) pole-pole array; (c) Schlumberger array; (d) gradient array; (e) dipole-dipole array (Modification from [18], [21]).

The resistivities values are mainly controlled by rock porosity and by the salinity of the pore waters because most minerals are insulators. Nevertheless, clay minerals are electrically polarized and rocks comprising them are extremely conductive while even slightly moist [21]. The resistivity value of several materials can be seen in Table 1 .

\section{METHODS}

Measurement conduct using resistivity tools Noniura NRD $328 \mathrm{HF}$. The type of array (configuration) applied was Schumberger Array. Measurement procedures done based on technique from: [14], [18], [21]

The measurement locations comprise; 1) T001-NS (Merauke), with $\mathrm{AB} / 2=250 \mathrm{~m}$; 2) T002-EW (Semangga), with $A B / 2=200 \mathrm{~m}$; (3) T003-NS
(Jagebob), with $\mathrm{AB} / 2=250 \mathrm{~m}$; (4) T004-NS (Kurik), with $\mathrm{AB} / 2=200 \mathrm{~m}$.

Table 1. The resistivity values materials [18], [25].

\begin{tabular}{|l|c|}
\hline \multicolumn{1}{|c|}{ Materials } & $\begin{array}{c}\text { Resistivity } \\
(\text { Ohm m })\end{array}$ \\
\hline Topsoil & $50-100$ \\
\hline Clay & $1-100$ \\
\hline Sandy clay & $80-1050$ \\
\hline Sandstone & $1-6.4 .10^{8}$ \\
\hline Sand & $1-1000$ \\
\hline Alluvium & $10-800$ \\
\hline Gravel & $100-600$ \\
\hline Saline sand and gravel & $0,5-5$ \\
\hline Meteoric water & $30-10000$ \\
\hline
\end{tabular}




\begin{tabular}{|l|c|}
\hline \multicolumn{1}{|c|}{ Materials } & $\begin{array}{c}\text { Resistivity } \\
(\mathrm{Ohm} \mathrm{m})\end{array}$ \\
\hline Meteoric water (igneous) & $0,1-3000$ \\
\hline Meteoric water (sedimentary rock) & $10-100$ \\
\hline Groundwater & $0,5-300$ \\
\hline Seawater & 0,2 \\
\hline Water (salinity 3\%) & 0,15 \\
\hline Water (salinity 20\%) & 0,05 \\
\hline
\end{tabular}

The resistivity technique has its beginning in the 1920 's as a result the work of the Schlumberger brothers (Loke, 2004; Moon et al., 2006). For around the next 60 years, for quantitative interpretation, conventional sounding surveys [26] were usually used. In this method, the centre point of the electrode configuration remains fixed, but the spacing among the electrodes is enlarged to attain more evidence about the deeper sections of the subsurface. Ideally, the distance $\mathrm{MN}$ is fixed, but in reality, because of the limitation equipment, when the distance of $\mathrm{AB}$ is increasing, the distance of $\mathrm{MN}$ should be change but no more than $1 / 5 \mathrm{AB}$. The apparent resistivity from field measurement is subsequently processed by IPI2win software to determine the true resistivity values. The definitive aim of this resistivity survey is to determine the resistivity distribution with depth on the basis of surface investigation of the apparent resistivity and to interpret it in terms of geology and hydrogeology [14], [24].

\section{RESULT AND DISCUSSION}

\subsection{Geology}

Merauke City, predominantly comprises unconsolidated brittle clastic deposit Quaternary Surficial Deposits of Young River Deposits (Qr 1), Older Swamp Deposits (Qs 2) and Coastal Deposits (Qc) (Figure 2) [27], [28]. The Young River Deposits present as, comprising sands, mud and pebbles deposited as flood plain. The Coastal Deposits consist of mud and finecoarse grain sands. The deposition of Qr 1 and Qc are still active [28].The Older Swamp Deposits consist of finegrained clastic deposits, mud and carbonaceous fine grained sands, and peat.

Based on aerial photographs and Landsat, the characteristic of the Qr 1 is light-medium grey in tone, texturally very smooth, with meandering drainage pattern, oxbow lakes, parallel ridges, and river terrace in place. On the other hand, the Qc is pale to dark gray, medium-fine texture, braided-meandering drainage pattern and ridge parallel to the beach line [28]. On the other hand, Qs 2 displays the tone of pale to dark grey, rough granular texture, with fine-dendritic to rectangular drainage pattern. The structure and tectonics in Merauke Regency predominantly is poorly recorded, with uplifting and resulted coastal and river terraces [27], [28].

\subsection{Resistivity Measurement Result}

Based on resistivity measurement, indication of seawater intrusions can be show in three locations, are Merauke City, Kurik and Semangga (Table 1 and Figure $3)$. In Jagebob, there was no indication in saline water intrusion. The area with saline groundwater present adjacent the beach area. The measurement point T001NS (Merauke District) comprise Coastal Deposits of mud and fine-coarse grain sands. This measurement point consists of five layers with resistivity from 1.07 to 470 ohm $\mathrm{m}$. The seawater intrusion present at 19.11 depth with resistivity $1.07-\mathrm{ohm} \mathrm{m}$.

The increasing of population impacts the growing in water consumption (household, agricultural, hotels, industry). The imbalance water exploitation and the lack of groundwater ability to recharge make the quality of groundwater decrease with seawater intrusion. Other factors are the permeable rock formation and the increasing use of depth wells. Migration of the fluids lengthways the aquifer and up along fractures effect in trapping of the brines below an impermeable cap [29].

The T002-EW (Semangga) is comprising sands, mud, and pebbles. The resistivity value of seawater intrusion is $0.794-o h m ~ m$ at $23.26 \mathrm{~m}$ depth in shallow well. The mechanism of intrusion probably occurred due to good ability of rock material to drain or flow the seawater. The increase of depth well in this area also made the intrusion progressively develop.

The T003-NS (Jagebob) is cover by vegetation and consist of fine-grained clastic deposits, mud and carbonaceous fine-grained sands, and peat. The population in this area is relatively lower than 3 other areas. There is no indication in seawater intrusion.

T004-NS (Kurik) has an eight km from coastal line. This area comprises Coastal Deposits of mud and finecoarse grain sands. There are five layers and indicated the seawater intrusion with $0.329-\mathrm{ohm} \mathrm{m}$ at $14.8 \mathrm{~m}$ depth The aquifer present at third layers with $8.01 \mathrm{ohm}-\mathrm{m}$. 


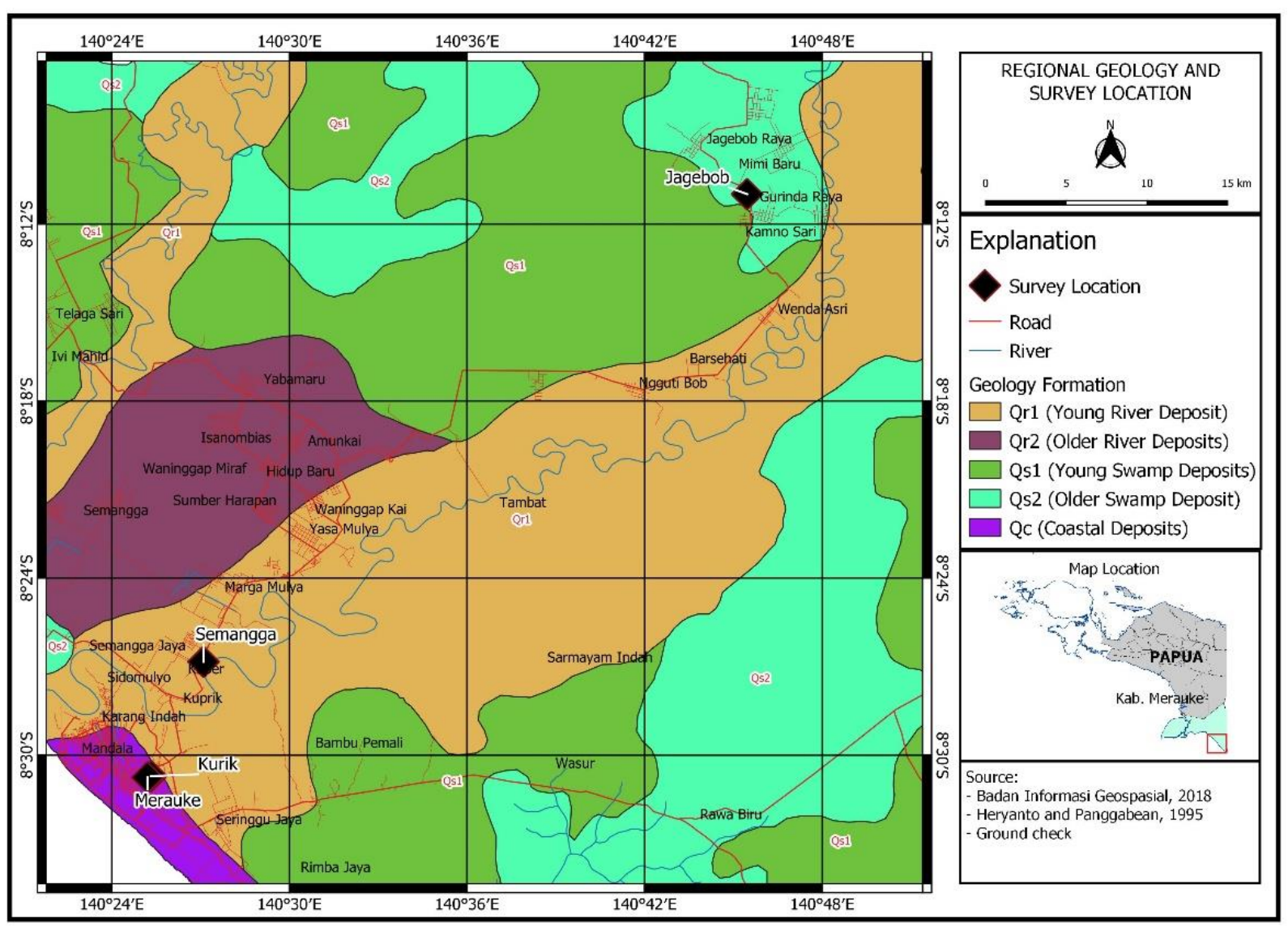

Figure 2 Geology of Merauke Regency (after Heryanto and Panggabean, 1995)

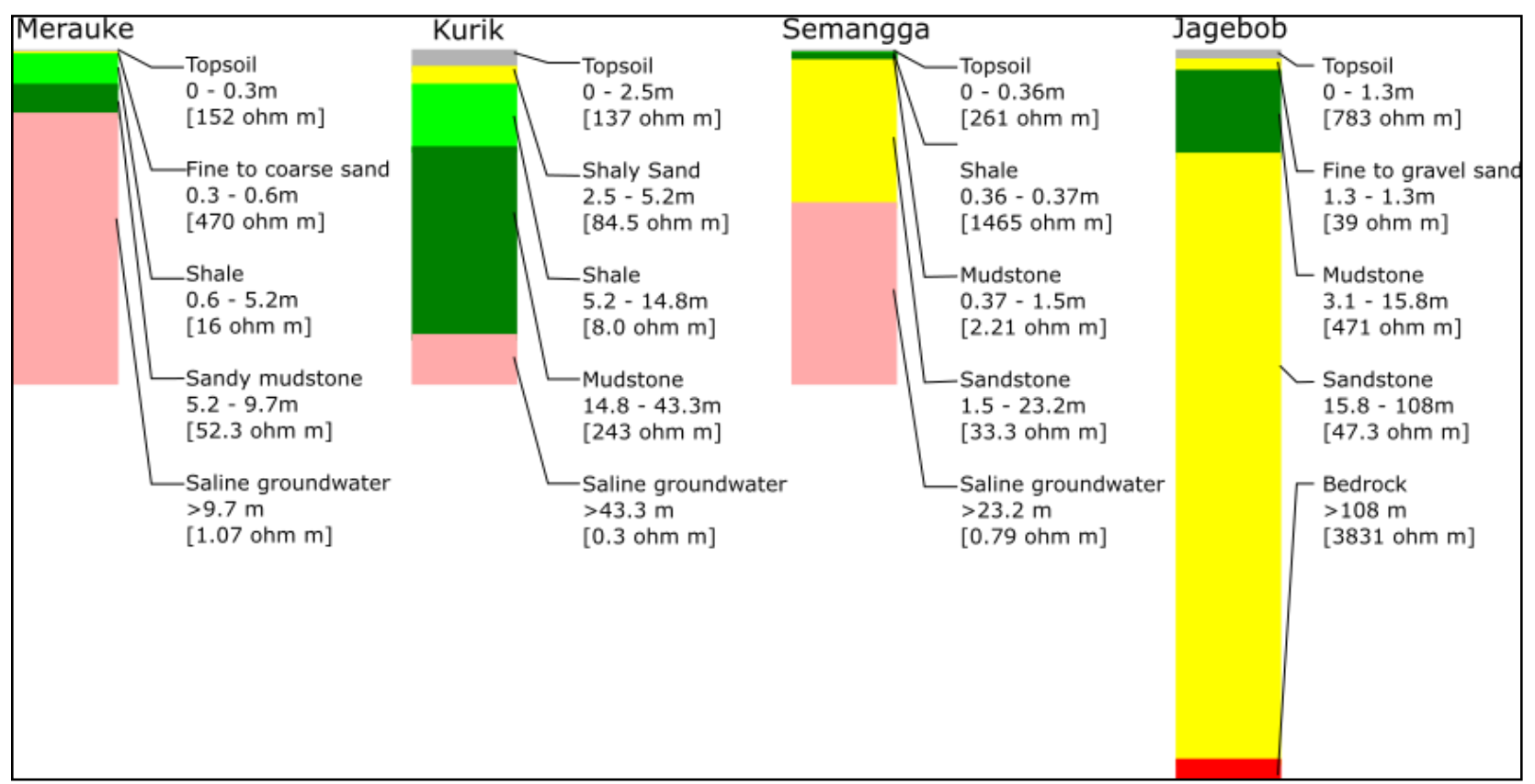

Figure 3 The resistivity value and saline water intrusion indication in Merauke, Kurik and Semangga. 
Porosity commonly increases with permeability. Permeability and porosity in sand and gravel, such as in research area, are relatively large because the sediment is relatively coarse and poorly packed, on the other hand, the fine-grained material generally reduced permeability or even barriers to flow [30]. The seawater intrusion develops in this area probably due to the characteristic of unconsolidated rock materials with high permeability and porosity and poorly packed. Other factor is imbalance between recharge and discharge of groundwater in water management use.

\section{CONCLUSION}

Based on resistivity data analysis, there are three locations on seawater intrusion indications. The three locations are Merauke, Semangga and Kurik. The saline groundwater resistivity is $1.07-\mathrm{ohm} \mathrm{m}$ at $19.11 \mathrm{~m}$ depth in Merauke: 0.794-ohm $\mathrm{m}$ at $23.26 \mathrm{~m}$ depth in Semangga, and $0.329-\mathrm{ohm} \mathrm{m}$ at $14.8 \mathrm{~m}$ depth in Kurik. There is no indication of seawater intrusion in Jagebob. The seawater intrusion present due to several factors; (1) the imbalance between recharge and discharge; (2) the characteristic of unconsolidated rock materials with high permeability.

\section{ACKNOWLEDGMENTS}

The authors would like to thank the principal financial and logistic supporters for this research; (1) Cenderawasih University; (2) Papua Province Government.

\section{REFERENCES}

[1] M. M. P. Hadiwidjoyo, "Kamus Geologi," (Dictionary of Geology and Closely Related Terrains). Badan Geologi, Departemen ESDM, Bandung, p. 250, 2013.

[2] N. Kresic, Hydrogeology and Groundwater Modeling. New York, USA: CRC Press, 2007.

[3] M. Allaby, "Oxford Reference," A Dictionary of Geology and Earth Sciences. Oxford University Press, 2013.

[4] Y. Zhou and W. Li, "A review of regional groundwater flow modeling," Geosci. Front., vol. 2, no. 2, pp. 205-2014, 2011, doi: 10.1016/j.gsf.2011.03.003.

[5] Virman, Identifikasi penyebaran akuifer berdasarkan distribusi tahanan jenis daerah buffer Waena-Entrop, Kota jayapura. Jayapura, 2013.

[6] M. Wibowo, "Potansi sumber daya air tanah di Surabaya berdasarkan survei geolistrik tahanan jenis. Jurnal Teknologi Lingkungan.," JurnalnTeknologi Lingkung., vol. 2, no. 1, pp. 5865, 2005.

[7] T. A. Ardaneswari, T. Yulianto, and T. T. Putranto, "Analisis intrusi air laut menggunakan data resisitivitas dan geokimia air tanah di dataran aluvial Kota Semarang," Youngster Physic, vol. 5, no. $4,2016$.

[8] A. R. Costall, B. D. Harris, B. Teo, R. Schaa, F. M. Wagner, and J. P. Pigois, "Groundwater Throughflow and Seawater intrusion in High Quality coastal Aquifers," Sci. Rep., vol. 10, no. 9866, pp. 1-33, 2020, doi https://doi.org/10.1038/s41598-020-66516-6.

[9] R. Meyer, P. Engesgaard, and T. Sonnenborg, "Origin and Dynamics of Saltwater Intrusion in a Regional Aquifer: Combining 3-D Saltwater Modeling With Geophysical and Geochemical Data," Water Resour. Res., vol. 55, pp. 17921813., 2019, doi: https://doi.org/10.1029/2018WR023624.

[10] Badan Informasi Geospasial, Atlas Overview Sumberdaya dan Lingkungan Provinsi Papua dan Papua Barat. 2016. [Online]. Available: http://www.big.go.id

[11] Badan Pusat Statistik, Рариа Dalam Angka. 2019.

[12] Virman, "Virman. 2019. Identification of groundwater quality of alluvium zona using geoelectric method of Schlumberger Configuration in Merauke City," presented at the ICASI Banda Ace Indonesia, 2019.

[13] A. G. A. Hewaidy, E. A. El-Motaal, S. A. Sultan, T. M. Ramdan, A. A. El Khafif, and S. A. Soliman, "Groundwater exploration using resistivity and magnetic data at the northwestern part of the Gulf of Suez, Egypt," Egypt. J. Pet., vol. 24, pp. 255263,2015 , doi: http://dx.doi.org/10.1016/j.ejpe.2015.07.010.

[14] M. H. Loke, Tutorial: 2-D and 3-D electrical imaging surveys. 2004.

[15] I. Muchingami, D. J. Hlatywayo, J. M. Nel, and C. Chuma, "Electrical resistivity survey for groundwater investigations and shallow subsurface evaluation of the basaltic-greenstone formation of the urban Bulawayo aquifer," Phys. Chem. Earth, vol. 50, no. 52, pp. 44-51, 2012, doi: dx.doi.org/10.1016/j.pce.2012.08.014.

[16] J. M. Reynolds, An Introduction to Applied and Enviromental Geophysics. New York, USA: John Wiley and Sons, 1997.

[17] E. S. Robinson and C. Coruh, Basic Exploration Geophysic. New York, USA: John Wiley and Sons, 1988.

[18] W. M. Telford, L. P. Geldart, and R. E. Sherrif, Applied Geophysics Second Edition.United Kingdom: Cambridge University Press. UK: Cambridge University Press., 1990.

[19] H. D. Ayu and A. Jufriadi, "Identifikasi Akuifer Air Asin Dan Air Tawar Berdasarkan Model Tahananjenis Dan Data Bor Di Sidoarjo, Jawa Timur," Ris. Geol. Dan Pertamb., vol. 30, no. 1, pp. 1-10, 2020, doi: 10.14203/risetgeotam2020.V30.1053.

[20] M. Goebel, A. Pidlisecky, and R. Knight, "Resistivity imaging reveals complex pattern of saltwater intrusion along Monterey coast," $J$. 
Hydrol., vol. 551, pp. 746-755, 2017, doi: http://dx.doi.org/10.1016/j.jhydrol.2017.02.037.

[21] C. J. Moon, M. K. G. Whateley, and A. M. Evans, Introduction to Mineral Exploration, 2nd ed. 350 Main Street, Malden, MA 02148-5020, USA 9600 Garsington Road, Oxford OX4 2DQ, UK 550 Swanston Street, Carlton, Victoria 3053, Australia: Blackwell Publishing, 2006.

[22] Wahyudin and H. Setiadi, "Pemetaan Hidrogeologi Skala 1:250.000," Badan Geologi, 58/LAP-BGE.P2K/2008, 2008.

[23] R. Marjoribanks, Geological Methods in Mineral Exploration and Mining, Second edition. Perth, Australia: Springer, 2010.

[24] M. Metwaly, E. Elwadi, S. S. R. Moustafal, F. Al Faouzan, S. Mogren, and N. Al Arifi, "Groundwater exploration using geoelectrical resistivity technique at Al-Quwy'yia area central Saudi Arabia," Int. J. Phys. Sci., vol. 7, no. 2, pp. 317-326, 2012, doi: DOI: 10.5897/IJPS11.1659.

[25] Muhardi, Faurizal, and Widodo, "Analisis pengaruh intrusi air laut terhadap keberadaan air tanah di Desa Nusapati, Kabupaten Mempawah Menggunakan Metode Geolistrik Resisitivitas.," Indones. J. Appl. Physic, vol. 10, no. 2, 2020.

[26] O. Koefoed, Geosounding Principles 1: Resistivity sounding measurements. Elsevier Science Publishing Company, Amsterdam. Amsterdam, Netherland: Elsevier Science Publishing Company, 1979.

[27] D. B. Dow, G. P. Robinson, U. Hartono, and N. Ratman, "Geology of Irian Jaya," 1988.

[28] R. Heryanto and H. Panggabean, "Geological Map of The Merauke Sheet, Irian Jaya," Geological Research And Development Centre, 1995.

[29] M. Kuhn, Reactive Flow Modeling of Hydrothermal Systems. Kensington, Perth, WA 6151, Australia: Springer-Verlag, 2004.

[30] J. Bridge and R. Demicco, Earth Surface Processes, Landforms and Sediment Deposits. Cambridge, USA: Cambridge University Press., 2008. 